Марина Мијајловић

Медицински факултет Универзитета у Крагујевцу

\title{
COST-EFFECTIVENESS ANALYSIS OF PREVENTING SUDDEN CARDIAC DEATH WITH AN IMPLANTABLE CARDIOVERTER DEFIBRILLATOR VERSUS AMIODARONE
}

\section{Marina Mijajlović}

Medical Faculty, University of Kragujevac

\section{СКРАЋЕНИЦЕ}

ИЦД - имплантибилни кардиовертер дефибрилатор

ICER - однос разлике у трошковима и разлике у ефектима новог и старог третмана (Incremental cost-effectiveness ratio)

QALY - добијене године живота кориговане за квалитет

РСД - динар Републике Србије

СЦД - изненадна срчана смрт

\section{САЖЕТАК}

Изненадна срчана смрт је природна смрт проузрокована претходном болешћу срца, када у року од једног сата од почетка симптома долази до губитка свести и престанка циркулације. Велики број студија је потврдио да су малигне аритмије из групе коморских аритмија најчешћи непосредни узрок изненадне срчане смрти. Алтернативе у превенцији изненадне срчане смрти су лечење антиаритмијским лековима и то превасходно амјодароном или уградња кардиовертер дефибрилатора. Циљ ове фармакоекономске студије је да се испита и упореди однос трошкова и клиничког ефекта имплантибилног кардиовертер дефибрилатора и амјодарона у превенцији изненадне срчане смрти. Дизајниран је Марковљев модел на основу података из литературе. Подаци су обрађени помоћу софтера TreeAge ${ }^{\circledR}$. Временски хоризонт је пет година. Трајање једног циклуса је месец дана. Ефекти за свако стање су изражени у добијеним годинама живота које су кориговане за квалитет. Симулација модела је извршена помоћу Монте Карло симулације за 1.000 хипотетичких пацијената. Имплантација кардиовертер дефибрилатора показала се као неисплатива метода превенције изненадне срчане смрти, скоро дванаест пута скупља од примене амјодарона односно 621.833,18 динара по добијеној години живота која је коригована за квалитет, наспрам 52.644,25 динара по добијеној години живота која је коригована за квалитет. Студија је указала да је кориснија метода у превенцији изненадне срчане смрти примена амјодарона, како због трошкова тако и због квалитета живота. Очекује се да ће резултати будућих истраживања указати на популацију код које ће имплантибилни кардиовертер дефибрилатор показати већу корисност у односу на амјодарон.

Кључне речи: амјодарон, имплантибилни кардиовертер дефибрилатор, трошкови, клинички ефекат 


\section{ABSTRACT}

Sudden cardiac death is natural death caused by previous heart disease, when within an hour from the onset of symptoms ensue loss of consciousness and cessation of circulation. Many studies have confirmed that malignant ventricular arrhythmias are the most common cause of sudden cardiac death. Alternatives for prevention of sudden cardiac death are antiarrhythmic drug treatment, primarily amiodarone, and implantation of cardioverter defibrillator. The aim of this pharmacoeconomic study was to compare the cost-effectiveness of implantable cardioverter defibrillator and amiodarone in preventing sudden cardiac death. The Markov model was designed based on data from the literature, and analyzed using the software TreeAge ${ }^{\circledR}$. The time horizon was five years. The duration of one cycle was one month. Effect for each model state was expressed in quality-adjusted life years gained (QALYs). The Monte Carlo simulation was used for 1.000 hypothetical patients. Implantation of cardioverter defibrillator proved to be pharmacoeconomically inferior method of preventing sudden cardiac death, nearly twelve times more expensive than applying amiodarone, i.e. $621.833,18$ dinars per QALY gained in comparison to 52.644,25 dinars per QALY gained for amiodarone. The study showed that the method with superior cost/effectiveness ratio was preventing sudden cardiac death by amiodarone. It is expected that further research will indicate a subpopulation in which the implantable cardioverter defibrillator will show better cost/effectiveness ratio than amiodarone.

Key words: amiodarone, implantable cardioverter defibrillator, costs, effectiveness

\section{УВОД}

Изненадна срчана смрт је неочекивана природна смрт настала због обољења срца у кратком временском периоду, у току једног сата од појаве симптома. Таква брза смрт се често приписује срчаним аритмијама. Продромални симптоми су често неспецифични ${ }^{1-3}$. Око $80 \%$ особа које доживе изненадну срчану смрт имају коронарну болест срца, тако да се епидемиологија изненадне срчане смрти у великој мери преклапа са коронарном болешћу срца а учесталост се повећава са годинама старости ${ }^{1}$. Постоји повезаност између механизма аритмије код изненадне срчане смрти и исхода реанимације. Када је иницијални ритам асистолија стопа преживљавања је мала. Исход је много бољи када је почетни ритам вентрикуларна тахиаритмија, јер око $25 \%$ болесника преживи, а када је у питању нестабилна вентрикуларна тахикардија стопа преживљавања је $65 \%$ до $70 \%{ }^{4}$. Стратегије за спречавање изненадне срчане смрти могу се поделити на две опште категорије: примарна превенција и секундарна превенција. Примарна превенција се односи на спречавање појаве вентрикуларне тахикардије, вентрикуларне фибрилације или срчаног удара. Секундарна превенција се односи на спречавање понављања потенцијално фаталних аритмија код пацијената који су имали клинички догађај тог типа. У оквиру обе категорије две најчешће алтернативе су коришћење антиаритмијских медикамената и уградња кардиовертер дефибрилатора (ИЦД) ${ }^{5-7}$.

Опсежна проспективна студија је указала да је амјодарон бољи избор од лидокаина са аспекта прогнозе пацијената код којих је наступио срчани застој рефрактеран на дефибрилацију у ванболничким условима, с тога је управо амјодарон упоређиван са ИЦД-ом кроз ову фармакоекономску анализу ${ }^{8}$. Преглед из домена ургентне фармакологије даје јасну терапијску препоруку, сумирањем великог броја студија, да је амјодарон данас лек избора у третману срчаног застоја изазваног шок-резистентном вентрикуларном фибрилацијом или вентрикуларном тахикардијом са одсуством пулса ${ }^{9}$. Ефикасност имплантибилног кардиовертер дефибрилатора се огледа у смањењу укупног морталитета, као и његових појединачних компоненти, изненадне срчане смрти, и смрти због аритмије. Поред самог смањења смртности за процену ефикасности су битни исплативост и квалитет живота. Тридесет до шездесет процената свих смртних случајева после инфаркта миокарда је директно изазвано коморским аритмијама ${ }^{7}$.

Циљ ове фармакоекономске студије је да ce упореди однос трошкова и клиничког ефекта имплантибилног кардиовертер дефибрилатора и амјодарона у превенцији изненадне срчане смрти.

\section{МАТЕРИЈАЛ И МЕТОДЕ}

У овој фармакоекономској студији извршена је анализа односа трошкова и клиничког ефекта два терапијска приступа у превенцији изненадне срчане смрти. Упоређивани су амјодарон и имплантибилни кардиовертер дефибрилатор. Дизајниран је Марковљев модел на основу вредности вероватноћа и кли- 
ничких ефеката из литературе $\mathrm{e}^{10-12}$. Подаци су обрађени помоћу софтера TreeAge ${ }^{\circledR 13}$. Ефекти за свако стање су изражени у добијеним годинама живота које су кориговане за квалитет. Временски хоризонт је пет година. Трајање једног циклуса је месец дана. Спремност да се плати је максималан износ које је дру- штво спремно да издвоји за годину живота кориговану за квалитет и у Републици Србији је дефинисана вредност на 1.500 .000 динара. Сви трошкови и ефекти су дисконтовани стопом од $3 \%$. Вероватноће и клиничка ефикасност догађаја су приказани у табелама 1 и 2.

Табела 1. Вероватноће догађаја после имплантације кардиовертер дефибрилатора и примене амјодарона

\begin{tabular}{|c|c|c|}
\hline Параметар & Вредност & Референца \\
\hline \multicolumn{3}{|c|}{ Вероватноће догађаја после имплантације кардиовертер дефибрилатора } \\
\hline Смрт током операције & 0,0030 & $\pi$ \\
\hline Смрт услед срчане инсуфицијенције & 0,0029 & II \\
\hline Смрт услед аритмије & 0,0020 & 12 \\
\hline Неаритмична срчана смрт & 0,1130 & 12 \\
\hline Несрчана смрт & 0,0024 & II \\
\hline Изненадна срчана смрт & 0,0015 & 11 \\
\hline Компликације имплантације & 0,0047 & 11 \\
\hline Престанак коришћења кардиовертер дефибрилатора & 0,0006 & 11 \\
\hline Неопходна замена после неуспеле имплантације & 0,0025 & 11 \\
\hline Наставак коришћења кардиовертер дефибрилатора & 0,9968 & 11 \\
\hline \multicolumn{3}{|c|}{ Вероватноће догађаја после примене амјодарона } \\
\hline Смрт услед срчане инсуфицијенције & 0,0029 & 11 \\
\hline Смрт услед аритмије & 0,0860 & 12 \\
\hline Неаритмична срчана смрт & 0,0500 & 12 \\
\hline Несрчана смрт & 0,0031 & 71 \\
\hline Изненадна срчана смрт & 0,0042 & 11 \\
\hline Токсичност & 0,1250 & 12 \\
\hline Акутна токсичност & 0,0180 & 12 \\
\hline Озбиљна токсичност (повлачење лека) & 0,8000 & 10 \\
\hline Смрт услед токсичности & 0,1820 & 10 \\
\hline Плућна токсичност & 0,1519 & 12 \\
\hline Остале токсичности & 0,8481 & 12 \\
\hline Реверзибилна плућна токсичност & 0,7500 & 12 \\
\hline Иреверзибилна плућна токсичност & 0,2500 & 12 \\
\hline
\end{tabular}

Табела 2. Квалитет живота појединих стања у моделу

\begin{tabular}{|l|c|c|}
\hline Стање & Квалитет живота & Референца \\
\hline \hline Живи након имплантације кардиовертер дефибрилатора & 0,88 & 10 \\
\hline Живи након компликација имплантације & 0,75 & 10 \\
\hline Живи након примене амјодарона & 0,88 & 10 \\
\hline Живи након токсичности амјодарона & 0,73 & 10 \\
\hline
\end{tabular}

Модел обухвата две терапијске алтернативе при чему сваког месеца пацијент носи одређен ризик од смрти услед аритмије и срчане инсуфицијенције, срчане смрти из других разлога, несрчане смрти, изненадне срчане смрти, компликација (код пацијената са имплантираним кардиовертер дефибрилатором) или токсичности (код пацијената који користе амјодарон). Пацијенти који имају имплантирани кардиовертер дефибрилатор су у додатном ризику од смрти током самог поступка уградње уређаја. Структура модела је дата на слици 1.

У ову фармакоекономску студију укључени су само директни медицински трошкови свих стања. Сви трошкови су рачунати према ценовнику Републичког фонда за здравствено осигурање и изражени су у динарима Републике Србије ${ }^{14}$. Трошкови имплантације кардиовертер дефибрилатора и самог уређаја добијени су на основу фактура Клиничког центра у Крагујевцу са одељења интервентне кардиологије (табела 3). Симулација модела је извршена помоћу Монте Карло симулације за 1000 хипотетичких пацијената, као и анализа сензитивности са варијацијом вредности параметара за $\pm 50 \%$. Као резултат истраживања добијен је однос трошкова и клиничког ефекта имплантације кардиовертер дефибрилатора и примене амјодарона изражен у РСД/QALY. 


\begin{tabular}{|l|l|c|c||}
\hline Tрошкови имплантибилног & \multicolumn{1}{|l|}{ Динари } \\
(PCД)
\end{tabular}

Табела 3. Трошкови терапије амјодароном и имплантибилним кардиовертер дефибрилатором

\section{Tornado Analysis (ICER)}

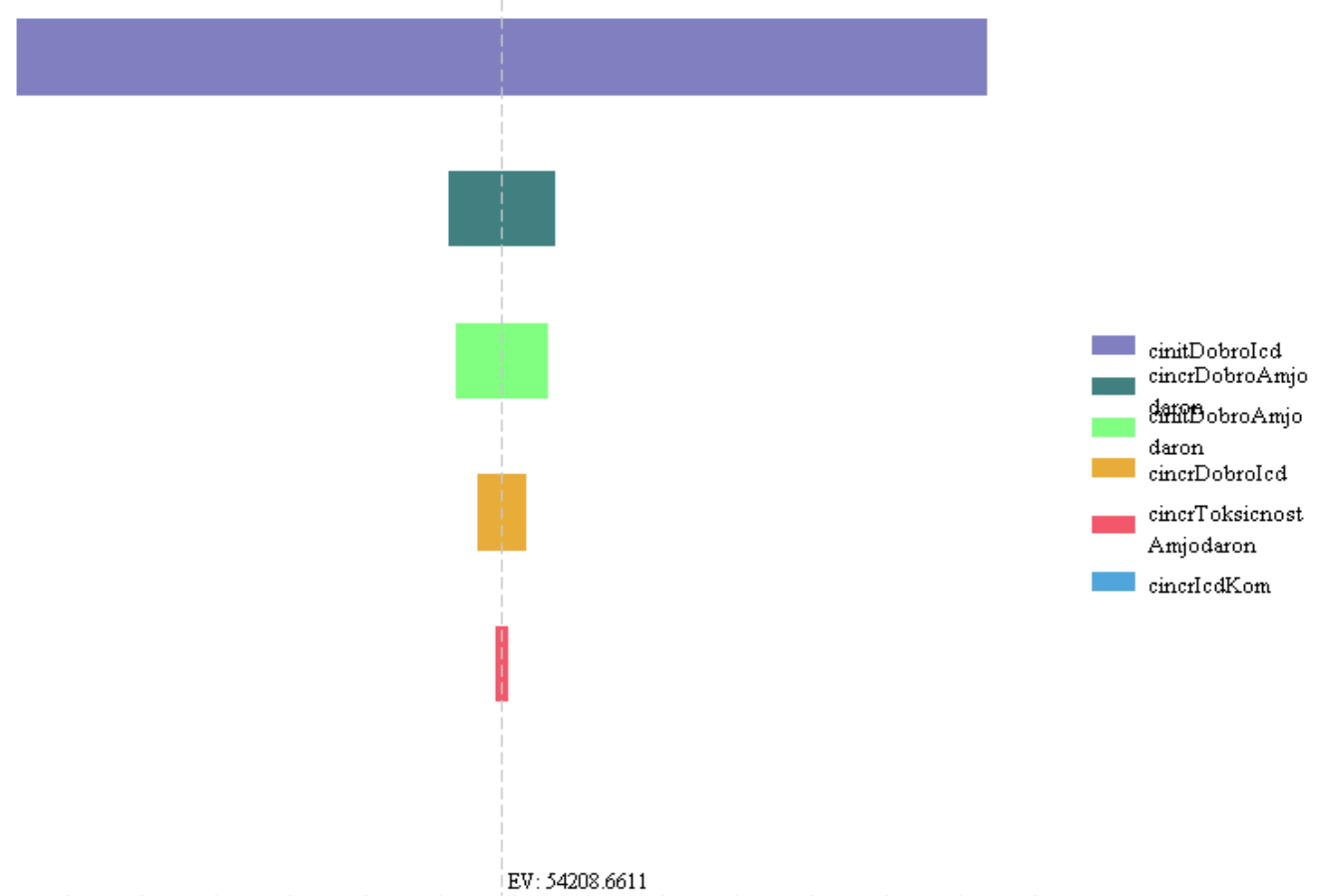

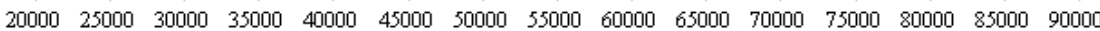

Слика 2. Анализа сензитивности 


\section{РЕЗУЛТАТИ}

После анализирања трошкова и клиничког ефекта две понуђене алтернативе у превенцији изненадне срчане смрти, као исплативија метода се показала примена амјодарона у односу на имплантацију кардиовертер дефибрилатора. Сами резултати указују да за имплантацију кардиовертер дефибрилатора у превенцији изненадне срчане смрти треба издвојити скоро дванаест пута више за једну годину живота кориговану за квалитет у односу на примену амјодарона, односно 621.833,18 РСД / QALY наспрам 52.644,25 РСД/1 QALY.

Спроведена је анализа сензитивности како би се проверила стабилност и тачност резултата, као и закључака фармакоекономске анализе при чему су вредности улазних варијабли вариране $\pm 50 \%$. Највећи утицај показују иницијални трошкови имплантације кардиовертер дефибрилатора, што указује да цена самог уградног материјала у највећој мери утиче на (не)исплативост овог поступка у превенцији изненадне срчане смрти (слика 2). Одмах након тога су иницијални трошкови терапије амјодароном, због високих трошкова мониторинга нежељених дејстава овог лека. Incremental cost/effectiveness ratio (ICER) представља однос разлике у трошковима и разлике у ефектима новог и старог третмана. У овом случају на основу података из Монте Карло симулације ICER износи -1 $858.524,043$. Слика 3 указује да имплантабилни кардиовертер дефибрилатор припада другом квадранту са мањом клиничком ефикасношћу и већим трошковима, тако да представља мање прихватљиву методу у овом случају. Са друге стране амјодарон припада четвртом квадранту (слика 4) са великом ефикасношћу и знатно мањим трошковима, па је самим тим то повољнија алтернатива која се препоручује у превенцији изненадне срчане смрти.

\section{Incremental Cost-Effectiveness, ICD v. Amjodaron}

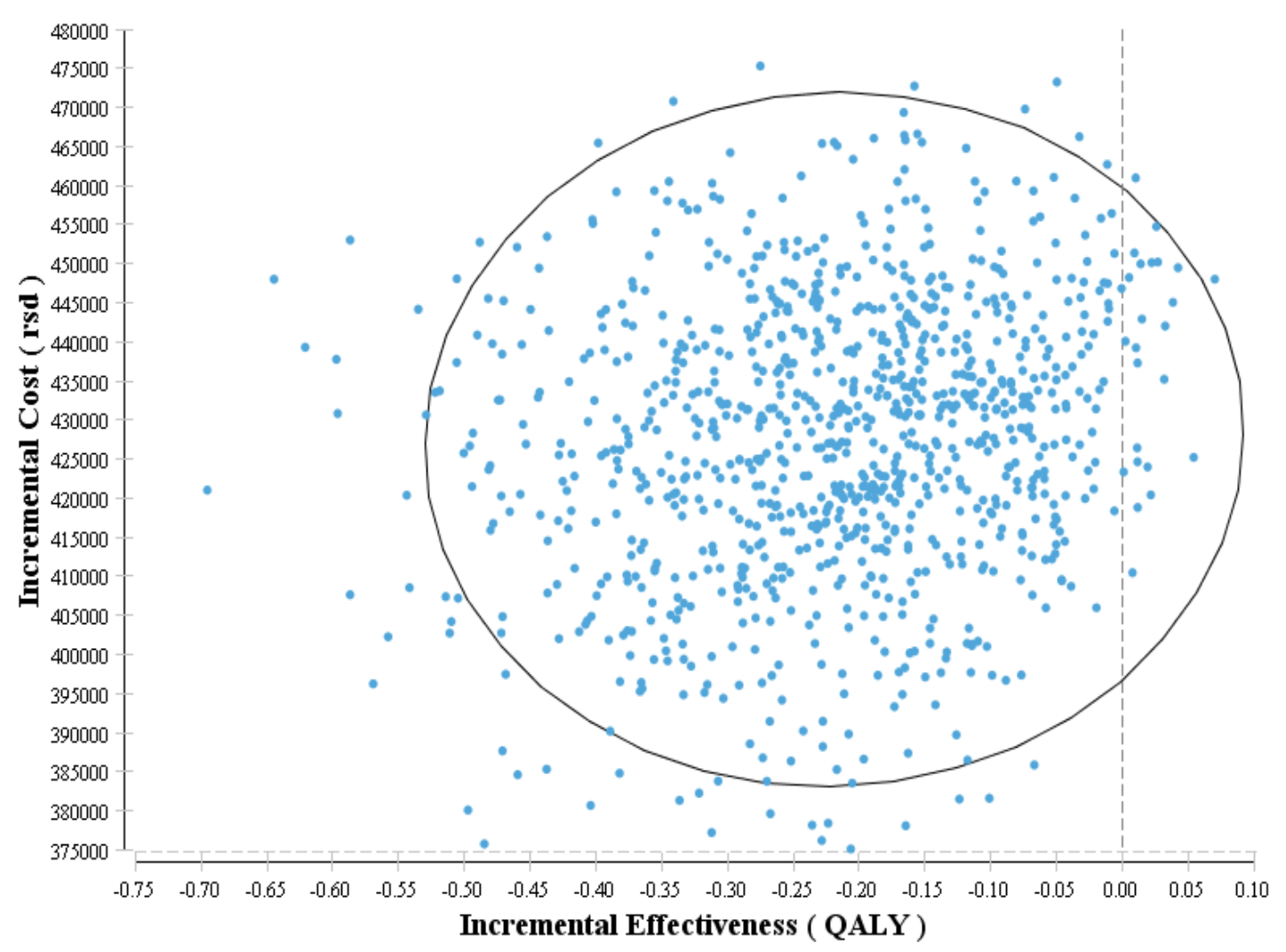

Слика 3. ICER график, имплантибилни кардиовертер дефибрилатор- амјодарон 


\section{Incremental Cost-Effectiveness, Amjodaron v. ICD}

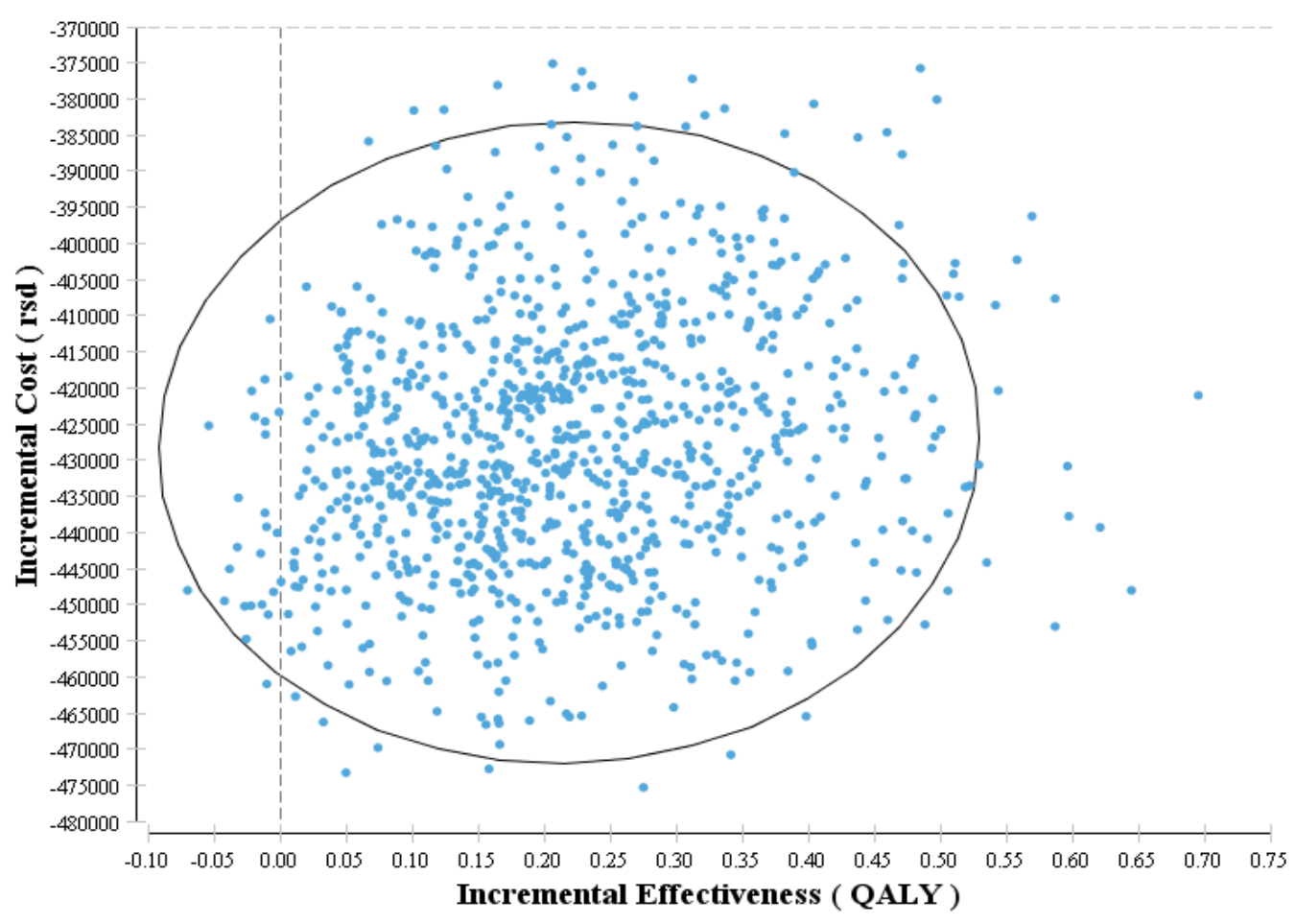

Слика 4. ICER график, амјодарон- имплантибилни кардиовертер дефибрилатор

\section{ДИСКУСИЈА}

Резултати нашег истраживања указују на неисплативост и неповољан однос трошкова и клиничког ефекта имплантације кардиовертер дефибрилатора у односу на примену амјодарона, за разлику од студије коју су спровели Sanders и сарадници где ИЦД доводи до бољег квалитета живота и већих расхода, док амјодарон доноси средњи квалитет живота и средње трошкове ${ }^{10}$. Профилактичка имплантација ИЦД-а у односу на конвенционалну терапију продужила је очекивани животни век за 2,22 године, и за $50 \%$ је смањена стопа изненадне срчане смрти у односу на групу са конвенционалном терапијом. У здравственим системима развијених европских земаља профилактичка имплантација ИЦД-а је исплатива ако кошта испод 50.000 еура по години продужења животног века код пацијената са повећаним ризиком од изненадне срчане смрти због смањене ејекционе фракције леве коморе $(\leq 35 \%)^{11}$. Мултицентрична рандомизирана студија је показала да ИЦД и антиаритмици имају сличан ефекат на квалитет живота пацијената са озбиљним вентрикуларним аритмијама. Појава симптома аритмија је повезана са значајним смањењем квалитета живота без обзира на терапијске стратегије ${ }^{15}$. Три недавне рандомизиране клиничке студије су показале да ИЦД редукује релативни ризик од смрти за $28 \%$ у поређењу са амјодароном код пацијената који су преживели вентрикуларну тахикардију или вентрикуларну фибрилацију, али уз велике трошкове. Трошак ИЦД терапије у Канади је 213.543 канадских долара по добијеној години живота. Због високе цене неопходно је тачно дефинисати групу пацијената којој је ИЦД користан како би се постигла економичност ${ }^{16}$. Трошкови знатно варирају у зависности од временског хоризонта: знатно се смањују како временски хоризонт расте, тако да се узак временски хоризонт од 5 година може сматрати као ограничавајући фактор наше студије ${ }^{17}$. Шокови имплантибилног кардиовертер дефибрилатора су одговарајући само у ситуацијама када су неопходни тј када су догађаји неизбежно фатални. Истраживање које су спровели Roderick и сарадници је открило да чак $25 \%$ пацијената добије неодговарајући шок. Управо ово је још један од фактора који утиче на смањење укупног квалитета живота и повећање учесталости депресије и анксиозности ${ }^{18}$. Код пацијената са неисхемијском дилатационом кардиомиопатијом и без постојања коморске тахиаритмије, имплантација кардиовертер дефибрилатора није повезана са било којим значајним дугорочним променама квалитета живота у пореЂењу са медикаментозном терапијом, што је указала и наша студија, тј сам имплантибилни 
кардиовертер дефибрилатор не доводи до побољшања квалитета живота ${ }^{19}$.

Резултати ове фармакоекономске студије су указали да лошији квалитет живота ових пацијената а уз то и висока цена самог уређаја сврставају имплантацију кардиовертер дефибрилатора у мање ефикасну методу у односу на конвенционалну терапију амјодароном. Из тих разлога, будућа употреба савремене алтернативе као што је имплантибилни кардиовертер дефибрилатор у Србији мора бити заснована на правилном одабиру пацијената са претходним инфарктом миокарда и високим ризиком од смрти због аритмија, како би се добио најбољи однос у економичности и добити.

\section{ЛИТЕРАТУРА}

1. Zipes DP, Wellnes HJJ. Sudden cardiac death. Circulation 1998; 98: 2334-51.

2. Myerburg RJ. Sudden cardiac death. Journal of Cardiovascular Electrophysiology 2001; 12: 369- 79.

3. Zheng ZJ, Croft JB, Giles WH, Mensah GA. Sudden cardiac death in United States, 1989 to 1998. Circulation 2001; 104: 2158- 63.

4. Antezano ES, Hong M. Sudden cardiac death. J Intensive Care Med 2003; 18: 313-27.

5. Huikuri HV, Castellanos A, Myerburg RJ. Sudden death due to cardiac arrhythmias. N Engl J Med 2001; 345: 1473- 82.

6. Goldberger JJ. Treatment and prevention of sudden cardiac death. Arch Intern Med 1999; 159: 1281- 86.

7. Boriani G, Biffi M, Martignani C et al. Cost- effectiveness of implantable cardioverter- defibrillators. Eur Heart J 2001; 22: 990-6.

8. Dorian P, Cass D, Schwartz B et al. Amiodarone as compared with lidocaine for shock- resistant ventricular fibrillation. N Engl J Med 2002; 346: 884- 90.
9. Jakovljević VM, Metiljević RZ. Amjodaron u urgentnoj terapiji komorskih aritmija pratilaca akutnog infarkta miokarda i srčanog zastoja. ABC časopis urgentne medicine 2007; 7: 7- 12 .

10. Sanders GD, Hlatky MA, Every NR et al. Potential costeffectiveness of prophylactic use of the implantable cardioverter defibrillator or amiodarone after myocardial infarction. Ann Intern Med 2001; 135: 870- 80.

11. Cowie MR, Marshall D, Drummond M et al. Lifetime cost- effectiveness of prophylactic implantation of a cardioverter defibrillator in patients with reduced left ventricular systolic function: results of Markov modeling in a Europen population. Europace 2009; 11: 716- 26.

12. Owens DK, Sanders GD, Harris RA et al. Cost- effectiveness of implantable cardioverter defibrillators relative to amiodarone for prevention of sudden cardiac death. Ann Intern Med 1997; 126: 1-12.

13. TreeAge Pro, 2006 TreeAge Software.

14. Ценовник Републичког фонда за здравствено осигурање, 2009.

15. Schron EB, Exner DV, Yao Q et al. Quality of life in the antiarrhythmics versus implantable defibrillators trial. Impact of therapy and influence of adverse symptoms and defibrillator shocks. Circulation 2002; 105: 589- 94.

16. Sheldon R, O'Brien BJ, Blackhouse G et al. Effect of clinical risk stratification on cost-effectiveness of the implantable cardioverter - defibrillator. The Canadian Implantable Defibrillator Study (CIDS). Circulation 2001; 104: 1622-6.

17. Al-Khatib SM, Anstrom KJ, Elstenstein EL et al. Clinical and economic implications of the multicenter automatic defibrillator implantation trial II. Ann Intern Med 2005; 142: 593-600.

18. Tung R, Zimetbaum P, Josephson ME. A critical appraisal of implantable cardioverter- defibrillator therapy for the prevention of sudden cardiac death. J Am Coll Cardiol 2008; 52: 1111-21.

19. Passman R, Subacius H, Ruo B et al. Implantable cardioverter defibrillators and quality of life. Arch Intern Med 2007; 167: 2226-32. 